\begin{abstract}
Prompted by recent concern about the stock status of the shortfin mako (Isurus oxyrinchus) in the North Atlantic Ocean, we examined reproductive data from 731 individuals (351 females and 380 males) collected by 3 scientific organizations to improve estimates of size and age at maturity. Males ranged in size from 70 to $283 \mathrm{~cm}$ fork length (FL) and females from 71 to $338 \mathrm{~cm}$ FL. Females matured between 263 and $291 \mathrm{~cm} \mathrm{FL,} \mathrm{with} \mathrm{an}$ estimated median length at maturity $\left(L_{50}\right)$ of $280 \mathrm{~cm} \mathrm{FL}$ and a median weight at maturity $\left(W T_{50}\right)$ of $275 \mathrm{~kg}$. Males matured between 173 and $187 \mathrm{~cm} \mathrm{FL}$, with an $L_{50}$ of $182 \mathrm{~cm} \mathrm{FL}$ and $W T_{50}$ of $64 \mathrm{~kg}$. Catch records from 4 international programs were also examined to investigate spatiotemporal variation in the distribution of life history stages based on updated size-at-maturity estimates and to identify potential parturition and nursery grounds. These records identified the Gulf of Mexico and the eastern North Atlantic Ocean off Portugal as birthing and nursery areas, with the most important nursery area occurring in the western North Atlantic Ocean.
\end{abstract}

\title{
Updated reproductive parameters for the shortfin mako (Isurus oxyrinchus) in the North Atlantic Ocean with inferences of distribution by sex and reproductive stage
}

\author{
Lisa J. Natanson (contact author) ${ }^{1}$ \\ Megan Winton ${ }^{2}$ \\ Heather Bowlby ${ }^{3}$ \\ Warren Joyce ${ }^{3}$ \\ Bethany Deacy ${ }^{4}$ \\ Rui Coelho 5 \\ Daniela Rosa 5 \\ Email address for contact author: lisa.natanson@noaa.gov \\ ${ }^{1}$ Northeast Fisheries Science Center \\ National Marine Fisheries Service, NOAA \\ 28 Tarzwell Drive \\ Narragansett, Rhode Island 02882 \\ ${ }^{2}$ Atlantic White Shark Conservancy \\ 235 Orleans Road \\ Chatham, Massachusetts 02650 \\ ${ }^{3}$ Bedford Institute of Oceanography \\ Fisheries and Oceans Canada \\ 1 Challenger Drive \\ P.O. Box 1006 \\ Dartmouth, Nova Scotia B2Y 4A2, Canada \\ ${ }^{4}$ Riverside Technologies Inc. \\ for Southeast Fisheries Science Center \\ National Marine Fisheries Service, NOAA \\ 3500 Delwood Beach Road \\ Panama City, Florida 32408 \\ ${ }^{5}$ Portuguese Institute for the Ocean and \\ Atmosphere \\ Avienida 5 de Outubro $\mathrm{s} / \mathrm{n}$ \\ 8700-305 Olhão, Portugal
}

The shortfin mako (Isurus oxyrinchus) is a large, highly migratory, coastalpelagic shark species in the family Lamnidae that occurs in temperate and subtropical seas worldwide (Bigelow and Schroeder, 1948). In the North Atlantic Ocean, this species is considered to consist of one stock that migrates throughout the North Atlantic Basin $\left(\right.$ ICCAT $\left.^{1}\right)$. Shortfin makos are commonly caught in both commercial and recreational fisheries throughout their range; although often not

Manuscript accepted 8 January 2020.

Fish. Bull. 118:21-36 (2020).

Online publication date: 30 January 2020.

doi: 10.7755/FB.118.1.3

The views and opinions expressed or implied in this article are those of the author (or authors) and do not necessarily reflect the position of the National Marine Fisheries Service, NOAA.
${ }^{1}$ ICCAT (International Commission for the Conservation of Atlantic Tunas). 2017. Report of the 2017 ICCAT shortfin mako assessment meeting (Madrid, Spain 12-16 June 2017), 42 p. ICCAT, Madrid, Spain. [Available from website.] the target species, they are frequently retained for their meat, fins, and jaws (Casey and Kohler, 1992; Babcock and Nakano, 2008). Although the species has long been considered vulnerable to overexploitation because of its late age at maturity, low reproductive potential, and commercial value (Dulvy et al., 2008; Cortés et al., 2010), catch levels were considered sustainable (ICCAT ${ }^{2}$ ). However, the results of an electronic tagging study conducted in 2013-2015

${ }^{2}$ ICCAT (International Commission for the Conservation of Atlantic Tunas). 2013. 2012 shortfin mako stock assessment and ecological risk assessment meeting (Olhão, Portugal-June 11 to 18, 2012). Collect. Vol. Sci. Pap. ICCAT 69:1427-1570. [Available from website.] 
indicate that fishing mortality rates in the North Atlantic Ocean may be 10 times higher than previously estimated, prompting an increase in concern about the status of the species (Byrne et al., 2017; ICCAT $^{1,3}$ ) and its listing as endangered on the IUCN Red List of Threatened Species in 2019 (Rigby et al., 2019).

The recent change in the estimated status of the stock has been attributed to improvements in available data as well as in the assessment model used $\left(\right.$ ICCAT $\left.^{1,4}\right)$. Shortfin mako assessments have traditionally been based on surplus production models, which pool recruitment, growth, and mortality into a single production function (Haddon, 2011). Such models have often been applied to assess the status of elasmobranchs lacking empirical estimates of vital rates and life history characteristics (Cortés, 2004), but they do not adequately depict the biology of the species. Because these models have not been adequate, the International Commission for the Conservation of Atlantic Tunas (ICCAT) has moved toward age-structured integrated approaches that incorporate estimates of important biological characteristics for the assessment of the North Atlantic Ocean stock of shortfin makos $\left(\right.$ ICCAT $\left.^{1}\right)$. Although the new assessment approaches will likely provide a better representation of the stock's dynamics, they require empirical estimates of biological parameters, as well as uncertainty associated with those estimates (Patterson et al., 2001; ICCAT $^{4}$ ).

Reproductive potential is a critical component to agestructured stock assessments and necessitates precise estimates of size and age at maturity, particularly for sexually dimorphic species (Quinn, 2003). However, maturity data are often lacking or unreliable for highly migratory pelagic sharks (Cortés, 1998, 2002); available estimates are often derived from sparse, opportunistic data sets (e.g., Francis and Duffy, 2005) or from samples originating in multiple ocean basins (Mollet et al., 2000). The most recent study on the reproductive biology of female shortfin makos was published in 2000 (Mollet et al., 2000), and there has never been a comprehensive study on male reproduction (although maturity estimates based on limited data are available; see Natanson et al., 2006, and Maia et al., 2007). The lack of data is largely due to difficulties in obtaining specimens representing all stages of maturity. In particular, mature females are rarely captured, either because they escape or break fishing gear (Pratt and Casey, 1983; Maia et al., 2007) or they are not in the commercial fishing grounds. Consequently, large mature females are seldom encountered by scientists, and estimates of maturity have often been based on a combination of reproductive data compiled from specimens collected in different areas.

\footnotetext{
${ }^{3}$ ICCAT (International Commission for the Conservation of Atlantic Tunas). 2017. Report of the Standing Committee on Research and Statistics (SCRS) (Madrid, Spain, 2 to 6 October 2017), 301 p. ICCAT, Madrid, Spain. [Available from website.]

${ }^{4}$ ICCAT (International Commission for the Conservation of Atlantic Tunas). 2019. Report of the 2019 ICCAT shortfin mako shark stock assessment meeting (Madrid, Spain 20-24 May 2019), 27 p. ICCAT, Madrid, Spain. [Available from website.]
}

Because life history variability arises through genetic isolation (Francis et al., 2007) as well as through differences in historical fishing pressure or environmental conditions (Tanaka et al., 1990; Bradley et al., 2017), combining data from multiple regions could be misleading and ultimately result in inappropriate management. Mollet et al. (2000) found significant differences in size at maturity between populations in the Northern and Southern Hemispheres, with females from the western North Atlantic Ocean being larger $(2.98 \mathrm{~m}$ total length [TL], compared with $2.73 \mathrm{~m}$ TL for females in the southern population). Although these data and conclusions are limited because of sample availability at the time, the value for females from the western North Atlantic Ocean (298.6 cm TL, which corresponds to $275.6 \mathrm{~cm}$ fork length [FL]) is currently used in stock assessments (ICCAT ${ }^{1}$. From limited sampling, it is difficult to determine how representative each estimate is of the entire population. A better understanding of reproductive potential would further increase the reliability of projections used for management advice.

In addition to their application in stock assessments, improved estimates of life history parameters can enhance understanding of the demographic characteristics of populations. For example, combining size and maturity information with spatial data could improve understanding of the demographic structure and seasonal movement patterns of the various life stages of shortfin makos (Barreto et al., 2016). For the population in the North Atlantic Ocean, ICCAT has requested the development of spatial management measures that promote conservation, with an initial focus on identifying birthing areas to improve management advice $\left(\right.$ ICCAT $\left.^{5}\right)$. For several species, the distribution of mature females has been used to infer breeding or parturition areas (Casey and Pratt, 1985; Coelho et al., 2018). The extent of overlap in the distributions of males and females may also provide insight into sexspecific selectivity or vulnerability to fisheries in specific locations or at specific times (Mucientes et al., 2009).

In this study, we updated the reproductive parameters of both male and female shortfin makos from the western North Atlantic Ocean, and we present here comprehensive estimates of median length at maturity $\left(L_{50}\right)$ and median weight at maturity $\left(W T_{50}\right)$ for males and females. We used the updated reproductive parameters to classify data collected in the broader North Atlantic Basin by life stage and examined potential variation in spatial and seasonal distributions by sex. We also examined locations and stages of mature females and neonates to identify possible parturition grounds and consider the distribution of youngof-the-year (YOY) shortfin makos to identify potential nursery areas.

\footnotetext{
${ }^{5}$ ICCAT (International Commission for the Conservation of Atlantic Tunas). 2017. Recommendation by ICCAT on the conservation of North Atlantic stock of shortfin mako caught in association with ICCAT fisheries. ICCAT Rec. 17-08, 3 p. [Available from website.]
} 


\section{Materials and methods}

Specimens of shortfin makos were collected from research cruises, recreational fishing tournaments, commercial fishing trips, and strandings along the northeastern coast of North America between Newfoundland, Canada, and the west coast of Florida, including the Gulf of Mexico, between 1971 and 2018. A subset of the female maturity data that were analyzed in this study $(n=61,17 \%)$ was previously used to estimate median $L_{50}$ by Mollet et al. (2000). Biologists from the Apex Predators Program and the Panama City Laboratory of the National Marine Fisheries Service (NMFS) and the Maritimes Region of Fisheries and Oceans Canada assessed maturity for 730 shortfin makos ( $n=675, n=20$, and $n=35$, respectively; Suppl. Table 1). Data collection was overseen by the senior author, and measurements were taken by experienced personnel by using a consistent sampling protocol. Full dissections (described later in the "Maturity indicators" section) were completed on the majority of specimens. However, because of time constraints at shark tournaments, it was not possible to perform a full workup of all specimens. In such instances, maturity for each sex was determined by visual examination only by using criteria based on detailed examinations as described later. Each shark was classified as mature or immature, and these data were used in calculating ogives for the analyses of median size at maturity (see the "Maturity indicators" and "Size at maturity" sections).

\section{Morphometrics}

Fork lengths were either measured directly (i.e., from the tip of the snout to the fork in the tail, over the body [OTB]) or calculated from OTB TL (i.e., from the tip of the snout to a point on the horizontal axis intersecting a perpendicular line extending downward from the tip of the upper caudal lobe to form a right angle) by using conversions from Kohler et al. (1995). In some cases, measurements were converted to straight-line $\mathrm{FL}\left(\mathrm{FL}_{\mathrm{S}}\right.$; these converted lengths are presented in parentheses) to facilitate comparison of lengths with those from other studies. Measurement of $\mathrm{FL}_{\mathrm{S}}$ was taken from the tip of the nose to the fork in the tail by placing a tape measure under the shark so that the body curvature was not included in the measurement. Linear regression was used to derive a conversion from $\mathrm{FL}_{\mathrm{S}}$ to $\mathrm{FL}_{\mathrm{OTB}}$ by using data collected during this study $(n=20)$. There was low variability around the fitted relationship (coefficient of determination $\left[r^{2}\right]=0.996$; Suppl. Fig. 1):

$$
F L_{\mathrm{S}}=0.1821+0.9792\left(F L_{\text {ОтВ }}\right)
$$

The equation derived by Francis (2006) was used to convert between $\mathrm{FL}_{\mathrm{S}}$ and straight-line $\mathrm{TL}\left(\mathrm{TL}_{\mathrm{S}}\right)$. Throughout the text, converted values are indicated by an asterisk $(*)$. Whole weight (WT) was taken when possible and is presented in kilograms.

\section{Maturity indicators}

Maturity indicators were developed from the organ measurement data collected during detailed dissections. We used the standardized terminology for dissection measurements from Hamlett (1999) and Hamlett and Koob (1999) and followed the protocols for measuring and weighing of reproductive organs detailed by Natanson and Gervelis (2013). Although most specimens were measured fresh, samples collected by commercial fishermen were frozen at sea and thawed prior to sampling in the laboratory. Measurements from the frozen tracts were used only if they fell within the range of the fresh measurements to minimize potential biases from extreme values. Maturity status was assigned to each shark in the field on the basis of visual inspection of reproductive organs as described later in the "Results" section. For specimens that were not classified at the time of dissection, maturity stage was later determined through comparison of organ measurements with maturity criteria derived from staged individuals (see the "Results" section). Morphometric measurements of the reproductive organs of both sexes were plotted against FL to show how growth of the reproductive system changed as an individual approached maturity. Reproductive organs grow rapidly when approaching maturity; therefore, the location of the inflection in these relationships relates to $L_{50}$.

Initial internal examination for female maturity noted presence or absence of embryos, ovulation, and presence or absence of nutritive capsules following Jensen et al. (2002). Prior mating activity was assessed on the basis of the presence or absence of a membrane over the urogenital sinus, which was determined by passing a probe through the posterior end of the uterus into the cloaca. For males, initial maturity was obtained by examining the external claspers manually for functionality by using 3 criteria: rotation, rigidity, and the ability of the rhipidion to splay (Clark and von Schmidt, 1965). Clasper length was measured from the posterior tip to the insertion of the pelvic fin (Pratt, 1996; outer clasper length as defined by Compagno, 2001). Siphon sacs were measured as per Natanson and Gervelis (2013).

All internal measurements (in millimeters) were taken at the widest portion of the organ from the right side of the shark. These measurements included the anterior oviduct width, oviducal gland width, uterus width and length, ovary width and length, and the largest yolked follicle for females and the siphon sac length and testis diameter and length for males. When possible, the ovary or testis was weighed to the nearest gram. Trophonemata were measured to the nearest millimeter when present. For sharks that did not undergo full dissection, the internal organs were visually assessed for maturity on the basis of the criteria from Natanson and Gervelis (2013); in particular, this assessment included a characterization of the epigonal tissue around the ovaries, follicle size and color, and the general appearance of the uterus and oviducal gland for females and a characterization of clasper condition and epigonal tissue around the testis for males. Individuals 
that appeared to have given birth in the current year were defined as postpartum, although those that had given birth, with indications of recovery, were considered in a resting stage (Castro, 2009).

\section{Size at maturity}

Median size at maturity was estimated for both sexes by using maturity ogives fit to binomial maturity data from both dissections and visual assessments. Data from all years were combined on the basis of the results of a preliminary analysis that indicated no evidence of variation in parameters between 2 time periods (1971-1987 and 2003-2018) (senior author, unpubl. data). The probability that a given individual $i$ was mature was modeled as the outcome of a Bernoulli random variable, where $y_{\mathrm{i}}=0$ for immature and $y_{\mathrm{i}}=1$ for mature individuals, respectively:

$$
y_{\mathrm{i}} \sim \operatorname{Bernoulli}\left(p_{\mathrm{i}}\right)
$$

where $p_{i}=$ the probability shark $i$ is mature.

We modeled $p_{i}$ as a function of size (separately in terms of FL and weight) as follows:

$$
\operatorname{logit}\left(p_{\mathrm{i}}\right)=\beta_{0}+\beta_{1} \text { Size }_{\mathrm{i}},
$$

where $\operatorname{logit}\left(p_{\mathrm{i}}\right)=$ the logit link function.

The function constrains $p_{\mathrm{i}}$ to values between 0 and 1;

$$
\beta_{0}=\text { an intercept term, and }
$$

$\beta_{1}=$ the effect of size in terms of either FL or weight.

Models were fit to each sex separately through maximum likelihood methods by using functions available in $\mathrm{R}$ (vers. 3.5.1; R Core Team, 2018). The inflection point of the relationship (where $P=0.5$ ) for either sex represents the median size at maturity (i.e., $L_{50}$ or $W T_{50}$ ) and was calculated from the fitted model parameters as $-\beta_{0} / \beta_{1}$. By using the boot package (vers. 1.3-20) in R (Canty and Ripley, 2017), 95\% confidence intervals around $L_{50}$ and $W T_{50}$ were bootstrapped from fits of a binomial generalized linear model to 1000 resamples of the maturity data (Harry et al., 2013). Given the well-established relationship between size and maturity and previously documented differences in size at maturity between male and female shortfin makos (Natanson et al., 2006), we did not conduct formal model selection in this study. For all models, normalized diagnostic plots of the residuals were examined visually to evaluate the appropriateness of model assumptions (Zuur et al., 2010).

\section{Demographic structure}

To investigate the spatial distribution of the population by life stage, shortfin mako catch records were obtained from 4 long-term, fishery-dependent sampling programs: 1) NMFS Cooperative Shark Tagging Program, 1962-2017; 2) NMFS Pelagic Observer Program, 1992-2017; 3) Canadian At-Sea Observer Program from the Maritimes region,
1979-2018; and 4) Portuguese Institute for the Ocean and Atmosphere onboard pelagic longliners from the Portuguese fleet, 2008-2016 (Suppl. Table 2). Data from 18,119 shortfin makos were used in distribution analyses, with the majority of samples $(87 \%)$ collected from west of longitude $45^{\circ} \mathrm{W}$. These data include date, size, sex, and location (Suppl. Table 2).

Females $(n=9310)$ ranged in size from 23.0 to $325.0 \mathrm{~cm}$ $\mathrm{FL}_{\mathrm{OTB}}$. Only 22 of those females were classified as mature on the basis of an $\mathrm{FL}_{\mathrm{OTB}}>291.0 \mathrm{~cm}$ (the length of the largest immature female observed; Tables 1 and 2). Males $(n=8809)$ ranged in size from 25.0 to $310.0 \mathrm{~cm}$, and 1174 of those males were considered mature on the basis of an $\mathrm{FL}_{\mathrm{OTB}}>187.1 \mathrm{~cm}$ (the length of the largest immature male observed; Tables 1 and 3). The 5 largest males in the data set were larger than the verified size limit for male shortfin makos. Attempts to confirm the accuracy of the sizes through the original archived data were inconclusive; therefore, caution should be exercised in taking these values as a new size range for male shortfin makos. Regardless, they would be classified as mature males and, for that reason, were included in our analyses. The majority of the catch data provide lengths in $\mathrm{FL}_{\mathrm{S}}$; therefore, for these analyses, measurements provided as $\mathrm{FL}_{\mathrm{OTB}}$ or $\mathrm{TL}_{\mathrm{S}}$ were converted to $\mathrm{FL}_{\mathrm{S}}$, as described previously. In instances where $\mathrm{TL}_{\mathrm{OTB}}$ or WT had been previously converted to $\mathrm{FL}_{\mathrm{OTB}}$, we assessed maturity on the basis of $\mathrm{FL}_{\mathrm{OTB}}$ rather than apply a second conversion; this approach was deemed reasonable given our conservative rationale for maturity classification (see the next paragraph). All estimated $\mathrm{FL}_{\mathrm{S}}$ were considered $\mathrm{FL}_{\mathrm{S}}$ (Suppl. Table 2).

Shortfin mako catch records were assigned to sex-specific maturity stages, representing neonate, YOY, immature, or mature individuals as follows: shortfin makos $\leq 68 \mathrm{~cm} \mathrm{FL}_{\mathrm{OTB}}$ were considered neonates on the basis of the average size at birth $\left(63.2 \mathrm{~cm} \mathrm{FL} \mathrm{OTB}^{*}\right)$ and the size of the largest fullterm embryo observed (estimated at $68 \mathrm{~cm} \mathrm{FL}_{\mathrm{OTB}}$ *; Mollet et al., 2000). Sharks $>68 \mathrm{~cm} \mathrm{FL}_{\text {OTB }}$ and $<100 \mathrm{~cm} \mathrm{FL}$ OTв were classified as YOY (Natanson et al., 2006). For the older age classes, $L_{50}$ estimates for males and females could be used to separate immature from mature sharks; however, misclassifications would result for both categories and distribution patterns potentially could be obscured because of individuals that fall into the transitional size range. To minimize the extent of overlap between the immature and mature sizes, sharks smaller than the smallest observed mature shark were considered immature. All sharks greater than the largest observed immature specimen by sex were considered to be mature. This method eliminated the portion of the length distribution during which maturity stage is the most uncertain and, therefore, the majority of the potential for differences in maturity stage to obscure distribution patterns.

To visualize potential variation in the spatial distribution of the life stages of shortfin makos, catch locations were binned by sex, maturity stage, and season and aggregated over a $1^{\circ}$-by- $1^{\circ}$ grid by using functions available in the $\mathrm{R}$ package tidyverse (vers. 1.2.1; Wickham, 2017). The seasons were winter (January-March), spring 


\section{Table 1}

Number of shortfin makos (Isurus oxyrinchus), by sex, captured per month in the western North Atlantic Ocean between 1971 and 2018 for maturity analyses and between 1962 and 2018 for investigation of demographic structure. Values for maturity analyses include both dissected and visually assigned specimens. I=immature; $\mathrm{T}=$ transitional (length range, where individuals are approaching maturity, bracketed by the smallest mature and largest immature female (263.0 and $291.0 \mathrm{~cm}$ FL, respectively); and $\mathrm{M}=$ mature.

\begin{tabular}{|c|c|c|c|c|c|c|c|c|c|c|}
\hline \multirow{3}{*}{$\begin{array}{l}\text { Month of } \\
\text { Capture }\end{array}$} & \multicolumn{2}{|c|}{ Maturity analyses } & \multicolumn{8}{|c|}{ Demographic structure } \\
\hline & \multirow[b]{2}{*}{ Male } & \multirow[b]{2}{*}{ Female } & \multicolumn{4}{|c|}{ Male } & \multicolumn{3}{|c|}{ Female } & \multirow[b]{2}{*}{$\bar{M}$} \\
\hline & & & Total & $\mathrm{I}$ & $\mathrm{T}$ & $\mathrm{M}$ & Total & $\mathrm{I}$ & $\mathrm{T}$ & \\
\hline January & 7 & 2 & 474 & 322 & 67 & 85 & 383 & 376 & 5 & 2 \\
\hline February & 0 & 2 & 394 & 243 & 69 & 82 & 317 & 311 & 4 & 2 \\
\hline March & 7 & 0 & 250 & 150 & 25 & 75 & 164 & 161 & 1 & 2 \\
\hline April & 7 & 3 & 507 & 301 & 107 & 99 & 273 & 271 & 1 & 1 \\
\hline May & 13 & 5 & 485 & 311 & 72 & 102 & 381 & 377 & 1 & 3 \\
\hline June & 166 & 126 & 893 & 744 & 75 & 74 & 1258 & 1255 & 3 & 0 \\
\hline July & 70 & 115 & 1650 & 1445 & 104 & 101 & 2254 & 2250 & 2 & 2 \\
\hline August & 85 & 88 & 1404 & 1169 & 102 & 133 & 1758 & 1753 & 3 & 2 \\
\hline September & 15 & 6 & 814 & 638 & 77 & 99 & 909 & 897 & 6 & 6 \\
\hline October & 8 & 2 & 814 & 607 & 95 & 112 & 710 & 709 & 1 & 0 \\
\hline November & 1 & 2 & 742 & 527 & 91 & 124 & 552 & 551 & 0 & 1 \\
\hline December & 0 & 0 & 382 & 252 & 42 & 88 & 351 & 346 & 4 & 1 \\
\hline
\end{tabular}

(April-June), summer (July-September), and fall (OctoberDecember) (Campana et al. ${ }^{6}$ ). The distribution of neonate and YOY catch records were examined for patterns related to pupping and nursery grounds.

\section{Results}

We examined 731 (351 female and 380 male) shortfin makos for maturity and completed full dissections of 197 females and 241 males. Females and males ranged in size from 70.6 to $338.5 \mathrm{~cm} \mathrm{FL}$ Отв and from 70.0 to $283.0 \mathrm{~cm}$ $\mathrm{FL}_{\text {OтB }}$, respectively (Fig. 1). Several male shortfin makos in this sample are larger than previously measured males (260 $\mathrm{cm} \mathrm{FL}$ Отв; Natanson et al., 2006); however, these measurements are verified and can be considered to represent an accurate size increase. The majority of specimens were collected from recreational fishermen at shark fishing tournaments in the United States (88\% sexes combined, $91 \%$ of females, and $86 \%$ of males; Suppl. Table 1) and between June and August (94\% of females and 85\% of males; Table 1). No specimens of either sex were obtained in December; males and females were caught in all other months with the exception of February and March, respectively (Table 1).

\footnotetext{
${ }^{6}$ Campana, S. E., J. Gibson, J. Brazner, L. Marks, and W. Joyce. 2008. Status of basking sharks in Atlantic Canada. Can. Sci. Advis. Secr. Res. Doc. 2008/004, 56 p. [Available from website.]
}

\section{Maturity indicators}

Females The relationships of the measurements of oviduct width, oviducal gland width, uterus diameter, ovary length, ovary width, ovary weight, and follicle diameter to FL indicate a sharp increase in size of $\sim 250-270 \mathrm{~cm}$ $\mathrm{FL}_{\text {ОтВ }}$, as exemplified by the relationship between the oviducal gland width and FL (Fig. 2, Suppl. Fig. 2). Only the relationship between FL and uterus length is essentially linear, indicating that growth of the uterus is relatively constant over ontogeny, rather than being indicative of size at maturity.

Immature females On the basis of organ measurements and the visual assessment used to assign status at dissection (full dissection: $n=170$; total: $n=325$ ), immature females ranged in length from 70.6 to $291.0 \mathrm{~cm} \mathrm{FL}$ Отв. Immature females have undeveloped ovaries with small follicles with little or no yolk; most follicles appear white to clear (Table 2). Maximum follicle size is generally $\leq 1 \mathrm{~mm}$ at this stage. Immature ovaries are embedded in epigonal tissue that progressively thins out in the larger immature females, ultimately becoming a thin, transparent sheath around the main ovary as the female matures. The immature uterus appears narrow and constricted with the oviducal gland appearing as a slight widening of the oviduct. Female shortfin makos $>250 \mathrm{~cm} \mathrm{FL}_{\text {Отв }}$ are starting to mature, and this transition to maturity is first observed in the development of the ovary. By the time a female is $250 \mathrm{~cm} \mathrm{FL}$ OTB, the ovary is clearly increasing 


\section{Table 2}

Size ranges of measurements and descriptions of organs used to determine maturity stages of female shortfin makos (Isurus oxyrinchus) captured in the western North Atlantic Ocean between 1971 and 2018. Sharks in the size ranges associated with the immature and mature stages generally conform to those assignments (unless otherwise noted), whereas sharks in the transitional range can be either immature or mature. Follicles classified as uncertain could indicate a specimen is transitional or mature. Table format adapted from Walker (2005). $n=$ number of specimens.

\begin{tabular}{|c|c|c|c|c|}
\hline Organ & Index & $\begin{array}{l}\text { Size range of } \\
\text { measurements }\end{array}$ & Description & $\begin{array}{c}\text { Maturity } \\
\text { classification }\end{array}$ \\
\hline \multicolumn{5}{|c|}{ Upper oviduct } \\
\hline \multirow[t]{3}{*}{$n=175$} & UO-1 & $\leq 7 \mathrm{~mm}$ & Thin tubular structure & Immature \\
\hline & UO-2 & $>7$ to $\geq 15 \mathrm{~mm}$ & & Transitional \\
\hline & UO-3 & $>15 \mathrm{~mm}$ & Thickened tubular structure & Mature \\
\hline \multicolumn{5}{|c|}{ Oviducal gland } \\
\hline \multirow[t]{4}{*}{$n=168$} & OG-1 & $\leq 11 \mathrm{~mm}$ & Undifferentiated from oviduct & Immature \\
\hline & OG-2 & $>11$ to $\leq 35 \mathrm{~mm}$ & $\begin{array}{l}\text { Increased width distinguishable from } \\
\text { oviduct }\end{array}$ & Probably immature \\
\hline & OG-3 & $>35 \mathrm{~mm}$ & Enlarged and bulbous & Probably mature \\
\hline & OG-4 & $>49 \mathrm{~mm}$ & Enlarged and bulbous & Mature \\
\hline \multicolumn{5}{|c|}{ Ovarian follicles } \\
\hline \multirow[t]{2}{*}{$n=111$} & OF-1 & $\leq 1 \mathrm{~mm}$ & Small and white & Immature \\
\hline & OF-2 & $>1 \mathrm{~mm}$ & Larger with yolk & Uncertain \\
\hline \multicolumn{5}{|c|}{ Ovary length } \\
\hline \multirow[t]{3}{*}{$n=166$} & OL-1 & $\leq 160 \mathrm{~mm}$ & $\begin{array}{l}\text { Clear follicles barely distinguishable from } \\
\text { epigonal }\end{array}$ & Immature \\
\hline & OL-2 & $>160$ to $\leq 210 \mathrm{~mm}$ & $\begin{array}{l}\text { White or opaque follicles distinguishable; } \\
\text { thinning epigonal }\end{array}$ & Transitional \\
\hline & OL-3 & $>210 \mathrm{~mm}$ & $\begin{array}{l}\text { Thin epigonal surrounding } \\
\text { cream- to yellow-colored yolked } \\
\text { follicles }^{\dagger}\end{array}$ & Mature \\
\hline \multicolumn{5}{|c|}{ Ovary width } \\
\hline \multirow[t]{3}{*}{$n=171$} & OW-1 & $\leq 50 \mathrm{~mm}$ & $\begin{array}{l}\text { Thin; follicles barely distinguishable from } \\
\text { epigonal }\end{array}$ & Immature \\
\hline & OW-2 & $>50$ to $\leq 110 \mathrm{~mm}$ & Widening area of distinguishable follicles & Transitional \\
\hline & OW-3 & $>110 \mathrm{~mm}$ & $\begin{array}{l}\text { Wide area of follicles surrounded by thin } \\
\text { epigonal }\end{array}$ & Mature \\
\hline \multicolumn{5}{|c|}{ Uterus length } \\
\hline \multirow[t]{3}{*}{$n=112$} & UL-1 & $\leq 280 \mathrm{~mm}$ & $\begin{array}{l}\text { Thin tubular structure indistinguishable } \\
\text { from upper oviduct }\end{array}$ & Immature \\
\hline & UL-2 & $>280$ to $\leq 470 \mathrm{~mm}^{\ddagger}$ & $\begin{array}{l}\text { Elongated tube, distinguishable from } \\
\text { lower oviduct }\end{array}$ & Transitional \\
\hline & UL-3 & $>470 \mathrm{~mm}$ & Large, often flaccid tubular structure & Mature \\
\hline \multicolumn{5}{|c|}{ Uterus width } \\
\hline \multirow[t]{3}{*}{$n=181$} & UW-1 & $\leq 38 \mathrm{~mm}^{\S}$ & Thin tubular structure & Immature \\
\hline & UW-2 & $>38$ to $\leq 70 \mathrm{~mm}$ & $\begin{array}{l}\text { Widening tube distinguishable from } \\
\text { upper oviduct }\end{array}$ & Transitional \\
\hline & UW-3 & $>70 \mathrm{~mm}$ & Large, distended tubular structure & Mature \\
\hline
\end{tabular}

${ }^{\dagger}$ Mature and transitional ovaries can appear similar.

* One specimen had a size larger than this range as a juvenile.

$\S$ One specimen had a size smaller than this range as an adult. 


\section{Table 3}

Size ranges of measurements and descriptions of organs used to determine maturity stages of male shortfin makos (Isurus oxyrinchus) captured in the western North Atlantic Ocean between 1971 and 2018. Sharks in the size ranges associated with the immature and mature stages generally conform to those assignments, whereas sharks in the transitional range can be either immature or mature. Table format adapted from Walker (2005). $n=$ number of specimens.

\begin{tabular}{|c|c|c|c|c|}
\hline Organ & Index & Size range of measurements & Description & Maturity classification \\
\hline \multicolumn{5}{|c|}{ Left clasper length } \\
\hline \multirow[t]{3}{*}{$n=237$} & LCL-1 & $\leq 185 \mathrm{~mm}$ & $\begin{array}{l}\text { Soft, do not freely rotate, do not } \\
\text { extend beyond pelvic fins, tip } \\
\text { does not flex }\end{array}$ & Immature \\
\hline & LCL-2 & $>85$ to $\leq 221 \mathrm{~mm}$ & $\begin{array}{l}\text { Soft to plastic, starting to rotate } \\
\text { and extend beyond pelvic fins, } \\
\text { tip does not flex }\end{array}$ & Transitional \\
\hline & LCL-3 & $>221 \mathrm{~mm}$ & $\begin{array}{l}\text { Rigid, freely rotate and flex at } \\
\text { tip, extend beyond pelvic fins }\end{array}$ & Mature \\
\hline \multicolumn{5}{|c|}{ Testis diameter } \\
\hline \multirow[t]{3}{*}{$n=209$} & TD-1 & $\leq 20 \mathrm{~mm}$ & Small testis encased in epigonal & Immature \\
\hline & TD-2 & $>20$ to $\leq 42 \mathrm{~mm}$ & $\begin{array}{l}\text { Larger testis, epigonal } \\
\text { decreasing in proportion }\end{array}$ & Transitional \\
\hline & TD-3 & $>42 \mathrm{~mm}$ & $\begin{array}{l}\text { Large testis with minimal } \\
\text { epigonal }\end{array}$ & Mature \\
\hline \multicolumn{5}{|c|}{ Testis length } \\
\hline \multirow[t]{3}{*}{$n=209$} & TL-1 & $\leq 70 \mathrm{~mm}$ & Thin testis encased in epigonal & Immature \\
\hline & TL-2 & $>70$ to $\leq 120 \mathrm{~mm}$ & $\begin{array}{l}\text { Elongated testis, distinguishable } \\
\text { from epigonal }\end{array}$ & Transitional \\
\hline & TL-3 & $>120 \mathrm{~mm}$ & $\begin{array}{l}\text { Long, distended testis from } \\
\text { epigonal }\end{array}$ & Mature \\
\hline \multicolumn{5}{|c|}{ Testis weight } \\
\hline \multirow[t]{3}{*}{$n=80$} & TW-1 & $\leq 45 \mathrm{~g}$ & & Immature \\
\hline & TW-2 & $\geq 45$ to $90 \leq \mathrm{g}$ & & Transitional \\
\hline & TW-3 & $>90 \mathrm{~g}$ & & Mature \\
\hline
\end{tabular}

in size, particularly in length (Fig. 3). An increase in size of all other organs can be seen in female shortfin makos $>250 \mathrm{~cm} \mathrm{FL}_{\text {OTB }}$ (Suppl. Fig. 2).

The transitional length range, where individuals are approaching maturity, is bracketed by the smallest mature and largest immature female $(263.0$ and $291.0 \mathrm{~cm}$ $\mathrm{FL}_{\mathrm{OTB}}$, respectively). In this range, organ measurements in an individual may or may not be in the mature size range. The majority of immature sharks (92\%) examined had a membrane separating the urogenital sinus from the cloaca. Of the $8 \%$ that did not, the majority $(70 \%)$ were approaching the transitional length range. In general, the transitional ovary is larger and contains larger follicles than the smaller immature ovaries; however, in most cases, the follicles are not as large as in the mature stages. In smaller transitional individuals, reproductive organs are in various stages of development. However, by the time a female is $260 \mathrm{~cm} \mathrm{FL}_{\mathrm{OTB}}$, organs are beginning to mature, as indicated by the marked increase in most morphometric measurements during the transitional length range (Fig. 2, Suppl. Fig. 3). In and of itself, this increase in growth does not demonstrate maturity because most individuals are still immature until $\sim 275 \mathrm{~cm} \mathrm{FL}$ OTB.

Mature females Adult females ranged from 263.0 to $338.5 \mathrm{~cm} \mathrm{FL} \mathrm{OTB}(n=26)$. Of those sampled, 3 were pregnant, 4 were postpartum, and 18 were staged as resting. The maturity stage of 1 specimen (either newly mature or resting) could not be determined with available information. The 3 pregnant females were $270.4,285.0$, and $301.0 \mathrm{~cm}$ $\mathrm{FL}_{\mathrm{O} \text { тв }}$ and were caught in January, February, and November, respectively, in the Gulf of Mexico. The largest trophonemata measured in this study ( 5 and $10 \mathrm{~mm}$ ) were taken from 2 of the pregnant females. The postpartum females ranged in length from 289.0 to $325.0 \mathrm{~cm} \mathrm{FL}$ OTВ. A recently postpartum female was caught in February in the Gulf of Mexico, and 3 specimens that had given birth within the season but had begun to recover were caught off Long Island in the summer (June: $n=2$; August: $n=1$ ). 


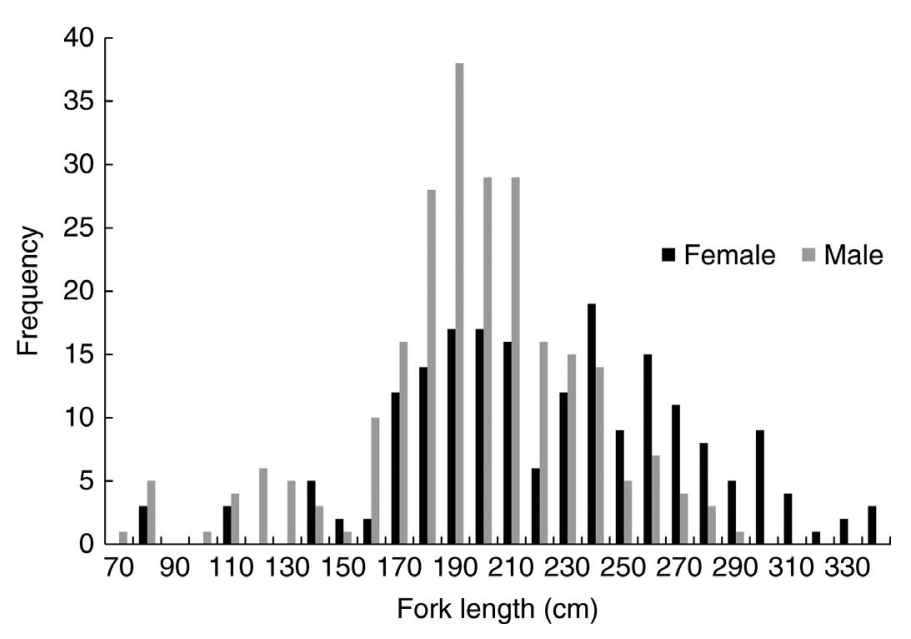

Figure 1

Size-frequency distributions for male $(n=243)$ and female $(n=197)$ shortfin makos (Isurus oxyrinchus) caught between the Gulf of Mexico and Newfoundland, Canada, during 1971-2018 and dissected for this study. $n=$ number of specimens.

alone, because of the similarity of some resting ovaries to some immature ovaries. Stage must be determined in combination with other organ characteristics, particularly follicle and uterus size and condition (Natanson and Gervelis, 2013). Resting stage females have expanded but recovered uteri indicating that they have previously given birth; some have small trophonemata $(0.0-1.5 \mathrm{~mm})$, and the condition of their ovaries indicates they had not given birth in the current season.

Males On the basis of organ measurements and the visual assessment used to assign status at dissection (full dissection: $n=241$; total: $n=379$ ), immature males ranged in length from 70.0 to $187.1 \mathrm{~cm} \mathrm{FL}$ отв (Suppl. Table 1). Measurements of clasper length (Fig. 4) verified visual accounts of the morphology during dissection, and a strong change in clasper growth rate at maturity was observed. Testis diameter, length, and weight as well as siphon sac size had approximately linear relationships with shark length, particularly after $\sim 150 \mathrm{~cm} \mathrm{FL}$ Отв (Fig. 5, Suppl. Fig. 3).

Clasper length, testis diameter, length, and weight, and siphon sac length show a rapid increase in growth at $\sim 150 \mathrm{~cm} \mathrm{FL}_{\text {Отв }}$ (Figs. 4 and 5, Suppl. Fig. 3), which levels off at $\sim 175 \mathrm{~cm} \mathrm{FL}$ for clasper length (Fig. 4). Siphon sacs are undeveloped and short in immature males, usually not extending far past the pelvic fins. There is a marked increase in growth once an animal reaches $\sim 150 \mathrm{~cm} \mathrm{FL}$ Oтв (Suppl. Fig. 3), and the siphon sacs expand anteriorly along the abdomen but do not reach the level of the pectoral fins by the time they fully develop. The degree of rigidity of the claspers is the best overall indicator of maturity. Mature males have rigid claspers, with the ability of the clasper to rotate freely and of the rhipidion to splay, whereas immature males do not have these qualities (Table 3). There were very few exceptions $(n=7)$ in which males did not have fully rigid claspers but had all other organs in the mature range, indicating that these males were approaching maturity. These specimens ranged in $\mathrm{FL}_{\text {Отв }}$ from 175.0 to $221.0 \mathrm{~cm}$, with the larger 3 males $(200.0-221.0 \mathrm{~cm}$

The large range of follicle sizes observed in the resting stage $(1.5-5.9 \mathrm{~mm})$ is most likely indicative of the amount of time the individuals had been recovering from their most recent parturition. Although females with follicles of $3.6 \mathrm{~mm}$ are usually mature (Table 2), it is difficult to classify these stages on the basis of appearance of the ovary
$\mathrm{FL}_{\mathrm{OTB}}$ ) having claspers that were partially rigid with sperm present and the smaller 4 specimens (175.0$187.4 \mathrm{~cm} \mathrm{FL} \mathrm{OTB}_{\text {OT }}$ ) having claspers that were soft and flexible. The latter fish were at the transitional size for male maturity (172.8-187.1 $\mathrm{cm} \mathrm{FL}_{\mathrm{OTB}}$ ). Immature males with rigid claspers $(n=4)$ ranged in size from 176.0 to $187.0 \mathrm{~cm}$ 

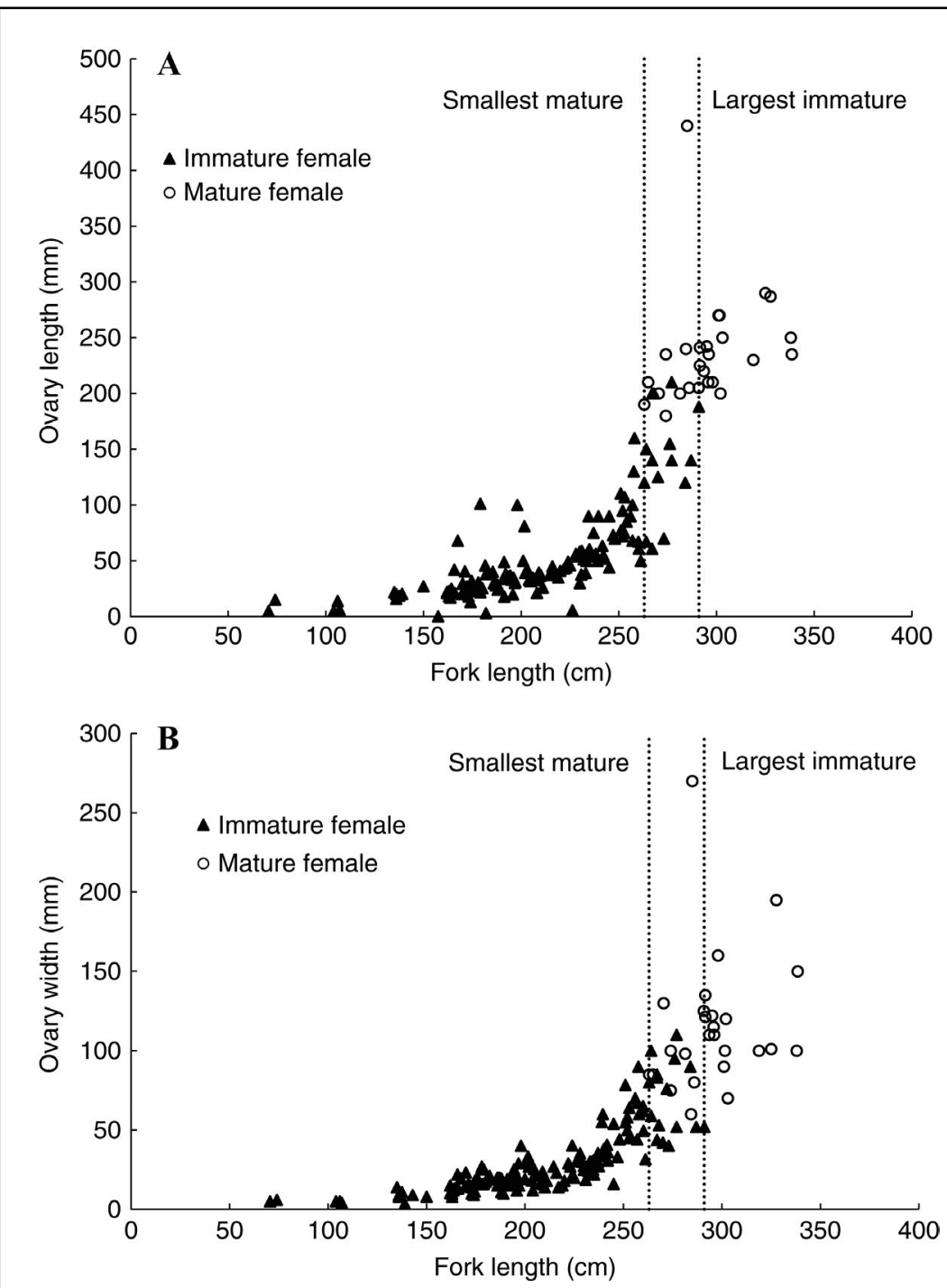

Figure 3

Relationship (A) of ovary length (in millimeters) to fork length (in centimeters) and (B) of ovary width (in millimeters) to fork length (in centimeters) of female shortfin makos (Isurus oxyrinchus) caught from the Gulf of Mexico to Newfoundland, Canada, during 1971-2018. Black triangles and open circles indicate specimens in the immature and mature stages, respectively. The vertical dotted lines represent the lengths of the smallest mature and largest immature specimens.

(95\% CI: 179.9-188.4) and the $W T_{50}$ was 63.8 kg (95\% CI: 62.0-74.0; Fig. 6). Converting both $L_{50}$ estimates into $\mathrm{FL}_{\mathrm{S}}$ for comparison with the catch data resulted in $274.2 \mathrm{~cm} \mathrm{FL}_{\mathrm{S}}$ for females and $178.0 \mathrm{~cm}$ $\mathrm{FL}_{\mathrm{S}}$ for males.

\section{Demographic structure}

On the basis of the estimated median size at maturity, $88 \%$ of the specimens were classified as immature; of these, immature females outnumbered immature males and mature males outnumbered mature females in all seasons (Table 1). Mature as well as immature animals of both sexes were caught in similar areas in all months, with the exception of mature females, which were not caught in June and October (Figs. 7 and 8, Suppl. Figs. 4 and 5). These movements could be related to shifts in the fishing fleets, but some generalizations can be made by season and sex. Although there were few captures of mature females, catches occurred in the Gulf of Mexico in fall and winter, shifting slightly onto the continental shelf in spring and summer. Young-of-the-year and neonate sharks were found primarily on the western side of the North Atlantic Ocean from the Gulf of Mexico up to the Flemish Cap with a small concentration in the northern Gulf of Mexico (Figs. 7 and 8).

\section{Discussion}

The reproductive parameters estimated in this study provide improved sexspecific inputs for stock assessment of shortfin makos in the North Atlantic Ocean. Our sampling was done throughout a vast geographical range and resulted in a data set that was an order of magnitude larger than those of previous studies on male or female reproduc-

$\mathrm{FL}_{\mathrm{OTB}}$, lengths that are also in the transitional range for maturity. Although individual variation exists in body length and in the order that organ development takes place, clasper calcification appears to be the last phase of maturation.

\section{Median length and weight at maturity}

The estimated $L_{50}$ for females was $279.8 \mathrm{~cm} \mathrm{FL}$ Oтв $(95 \%$ confidence interval [CI]: 273.8-286.6), and the estimated $W T_{50}$ for females was $274.8 \mathrm{~kg}$ (95\% CI: 255.4-274.0; Fig. 6). For males, the estimated $L_{50}$ was $181.6 \mathrm{~cm} \mathrm{FL} \mathrm{OTB}$ tion. Although our sampling was concentrated in the west, it is representative of the entire region, given the strong evidence for one population in the North Atlantic Ocean. Conventional tag and recapture data from 1148 shortfin makos indicate 1) mixing of individuals tagged in Europe and in the United States in an area west of the Azores of Portugal; 2) movement from the western to the eastern Atlantic Ocean; and 3) movement into and out of the Gulf of Mexico and the Caribbean Sea (Kohler and Turner, 2019). Our estimate of female $L_{50}(279.8 \mathrm{~cm} \mathrm{FL}$ OTB, $274.2 \mathrm{~cm}$ $\mathrm{FL}_{\mathrm{S}} *$ ) is slightly larger than the previous estimate by Mollet et al. (2000) (275 $\left.\mathrm{cm} \mathrm{FL}_{\mathrm{OTB}}{ }^{*}\right)$, although their value 


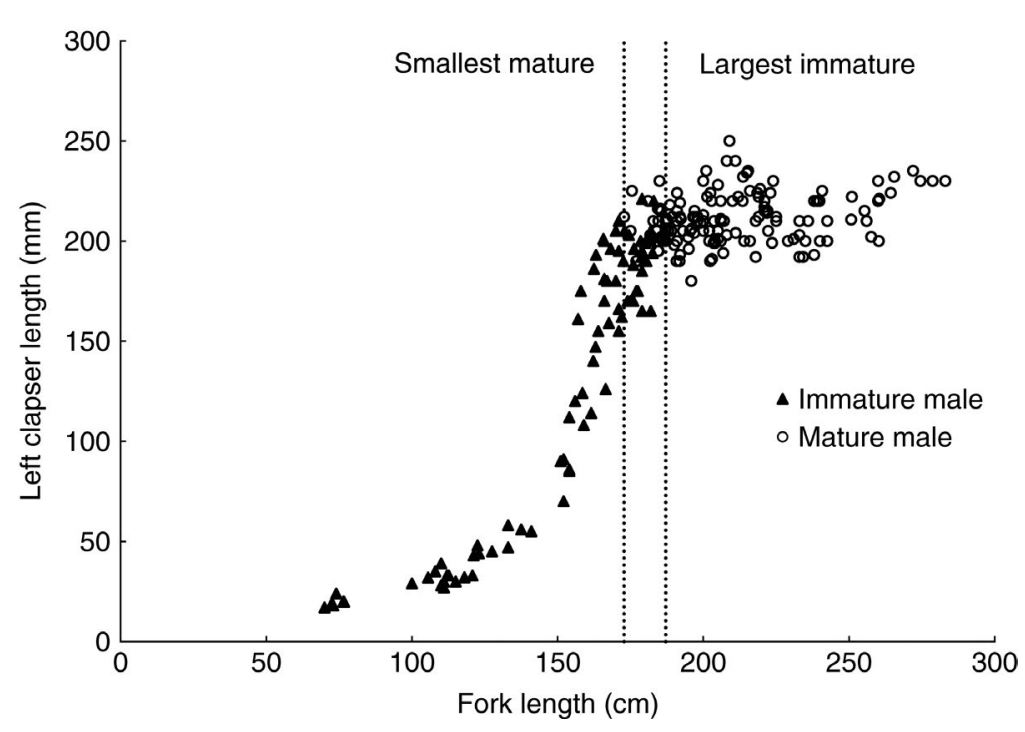

Figure 4

Relationship of left outer clasper length (in millimeters) to fork length (in centimeters) of male shortfin makos (Isurus oxyrinchus) caught between the Gulf of Mexico and Newfoundland, Canada, during 1971-2018. Black triangles and open circles indicate specimens in the immature and mature stages, respectively. The vertical dotted lines represent the lengths of the smallest mature and largest immature specimens.

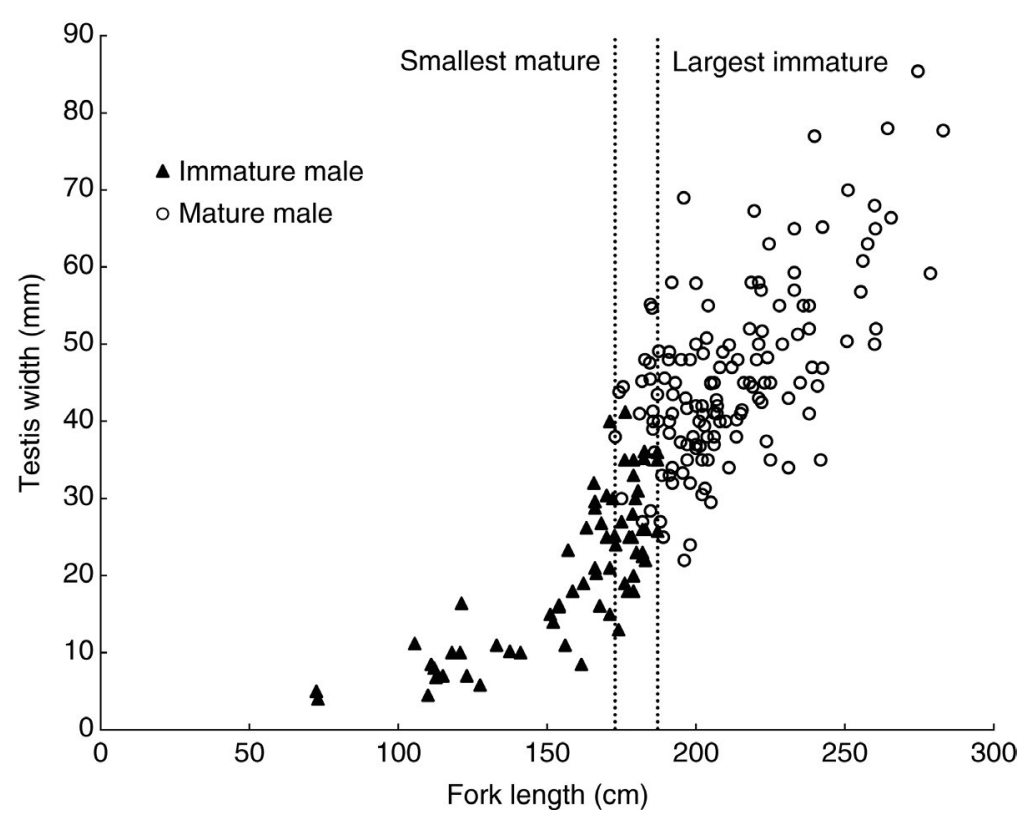

Figure 5

Relationship of right testis width (in millimeters) to fork length (in centimeters) of male shortfin makos (Isurus oxyrinchus) caught between the Gulf of Mexico and Newfoundland, Canada, during 1971-2018. Black triangles and open circles indicate specimens in the immature and mature stages, respectively. The vertical dotted lines represent the lengths of the smallest mature and largest immature specimens. is within the $95 \%$ CI of this study. Our estimate for male $L_{50}(181.6 \mathrm{~cm} \mathrm{FL}$ OTB, $\left.178.0 \mathrm{~cm} \mathrm{FL}_{\mathrm{S}}{ }^{*}\right)$ is similar to the previous estimate from a study in waters of Portugal in the eastern North Atlantic Ocean (180 cm FL

On the basis of existing age-length relationships, age at $L_{50}$ were estimated for males at 7.5 years (Natanson et al., 2006; Rosa et al. ${ }^{7}$ ); the estimate for females was slightly over 19 years, when following Natanson et al. (2006), and 22 years, when following Rosa et al. ${ }^{7}$ The dissection data provide a comprehensive view of the maturity of this species for the western North Atlantic Ocean, and the evidence for one stock supports the use of these data for characterizing maturity of the entire population in the North Atlantic Ocean. The fact that maturity estimates have not changed markedly over time increases our confidence in their accuracy, making our updated values the best available to describe maturity and to inform ageand sex-structured models used for stock assessment $\left(\mathrm{ICCAT}^{4}\right)$.

The growth patterns of individual reproductive organs indicate increased energetic investment in reproduction in advance of maturity in both male and female shortfin makos, although not all organs are as useful for distinguishing between immature and mature individuals. With the exception of uterus length, which grew gradually relative to length, measurements of internal reproductive organs of females increased sharply as sharks matured. Similar to Mollet et al. (2000), we found that uterus width and oviducal gland growth were suitable for distinguishing between immature and mature females and reproductive stage. Although the maximum follicle diameter also increases with FL (Mollet et al., 2000), there is overlap in follicle size between all maturity stages because of the nature of the lamnid ovary and mode of embryonic nutrition, indicating that follicle diameter alone is not useful for determining stage of maturity.

7 Rosa, D., F. Mas, A. Mathers, L. J. Natanson, A. Domingo, J. Carlson, and R. Coelho. 2017. Age and growth of shortfin mako in the north Atlantic, with revised parameters for consideration to use in the stock assessment. Int. Comm. Conserv. Atlantic Tunas, ICCAT SCRS/2017/111, 22p. [Working paper.] 


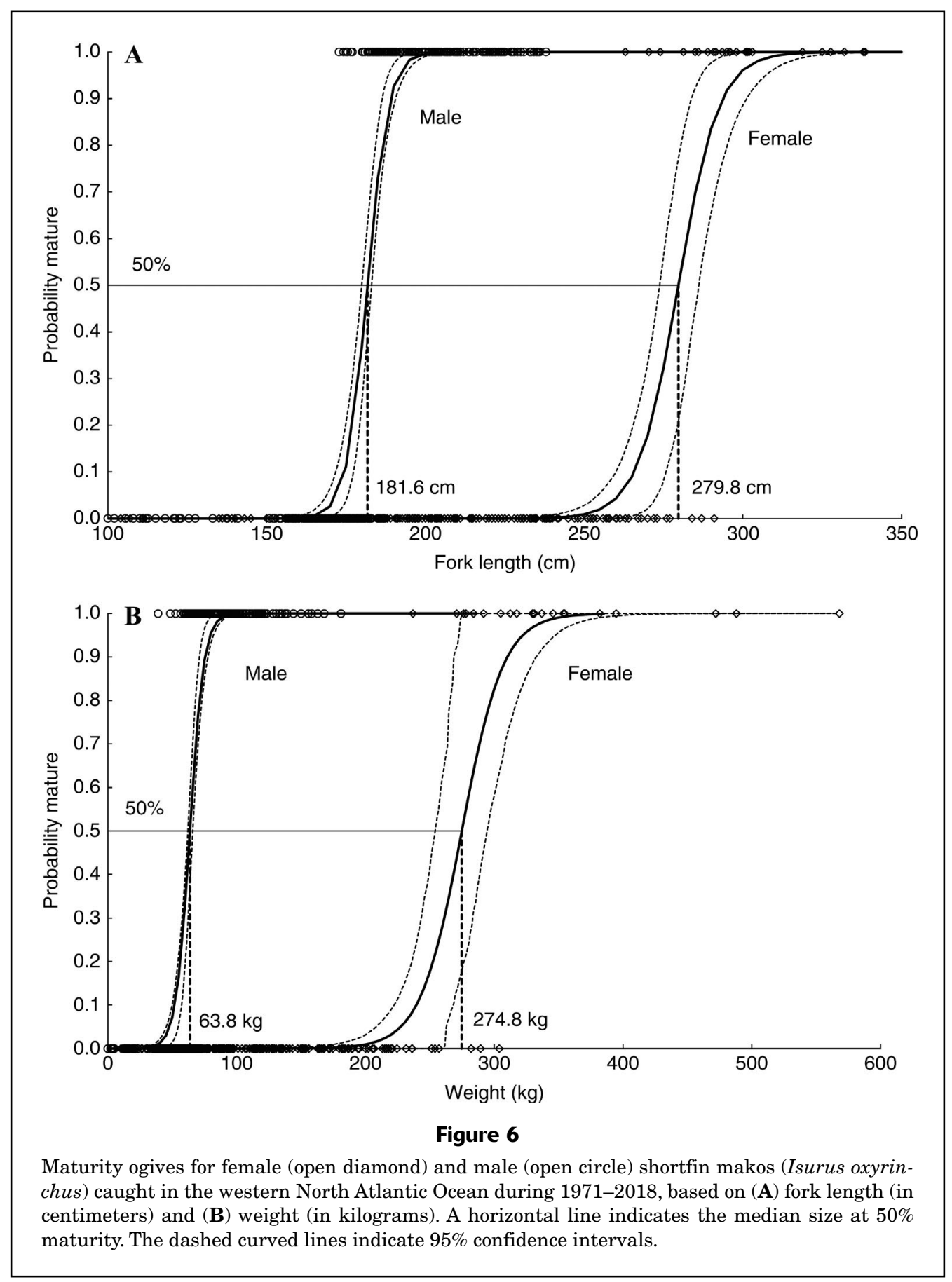

For males, clasper length and calcification are the most accurate means of determining maturity. It is not uncommon in elasmobranchs that the secondary sexual characteristics (including clasper rigidity, rotation, and the ability of the rhipidion to splay open) develop after the primary sexual organs and are the defining criteria for maturity (Clark and von Schmidt, 1965). At a minimum, future studies on the reproductive dynamics of shortfin makos should combine comprehensive visual assessments (e.g., presence or absence of embryos and condition of ovaries and uterus) with morphometric measurements (on the organs that show the most rapid growth to body size in females and on clasper length and rigidity in males) to accurately assign maturity stage.

The overlap observed in the demographic structure in the seasonal distributions of the 2 sexes as well as among the different life history stages of shortfin makos were unexpected, given that habitat partitioning and sex and size segregation is common in sharks (Haulsee et al., 2018). Immature males, adult males, immature females, and adult females were found together in every month, with the exception of June and October when mature 


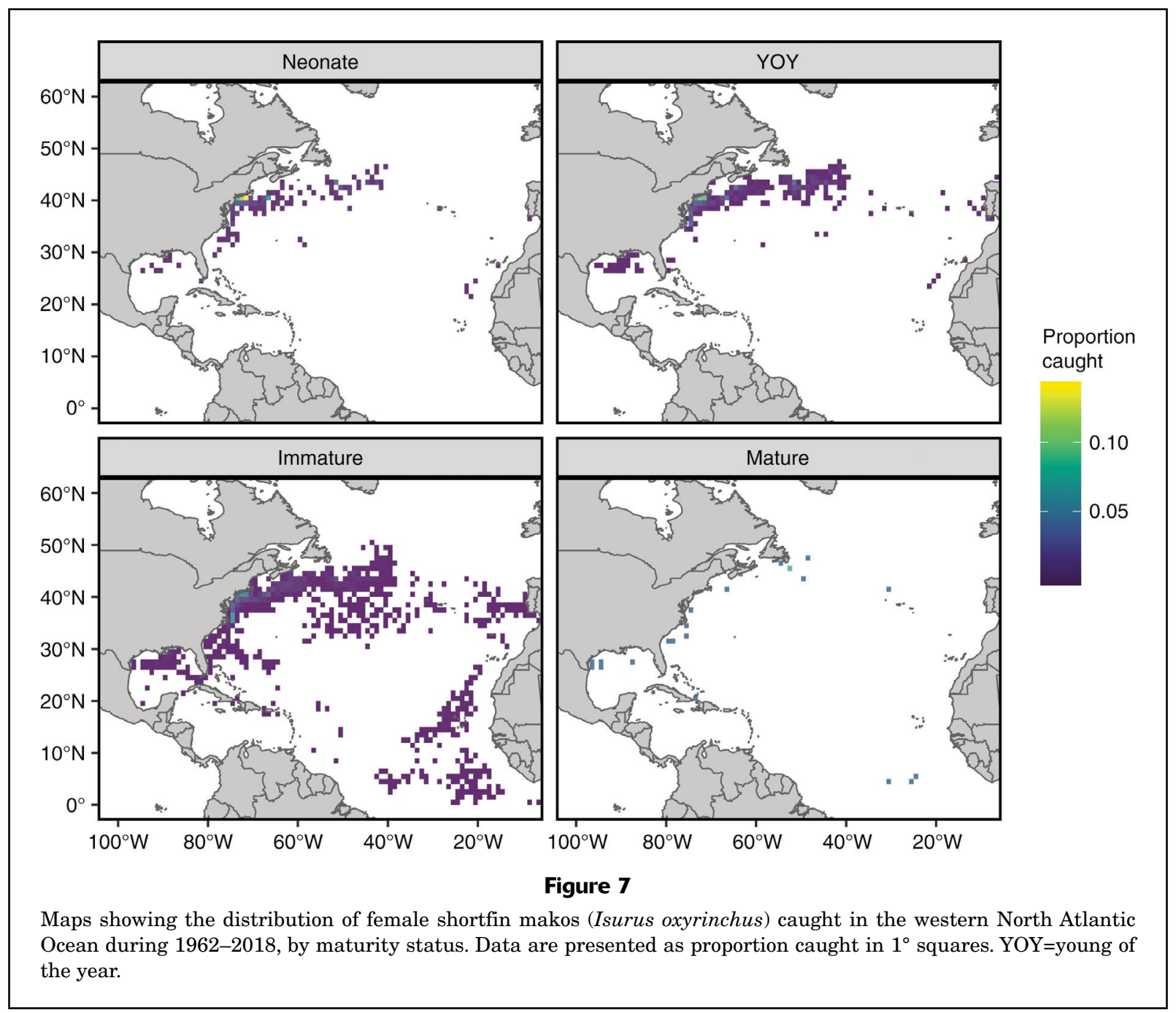

females were not caught. Segregation in space and in particular by depth has been previously reported for shortfin makos in the South Pacific Ocean, with males being predominantly found in the west and females in the east and with larger fish spending time at greater depths than smaller fish (Mucientes et al., 2009). Similar to Muicientes et al. (2009), more mature males were captured than mature females in our study, possibly as a result of mature females being absent from the areas targeted by commercial fishing operations or remaining at depths that are out of the range of the fishing gear.

Although the distribution data used in this study were spatially and temporally dependent on fishing effort, the same is true for the majority of data used in other studies to describe the distributions of pelagic sharks (Mucientes et al., 2009; Heupel et al., 2018). Some gear configuration changes (Federal Register, 2004; Coelho and MuñozLechuga, 2019) may have influenced the catchability of sharks over time (Reinhardt et al., 2018), but no management or systematic changes in the distribution of fishing effort would have affected the geographic range of the catch data used. The majority of the catch data used to infer distributions, however, originated from the western North Atlantic Ocean (87\% came from west of longitude $45^{\circ} \mathrm{W}$ ); therefore, there remains the possibility that spatial segregation occurs at a larger geographical scale. The fact that immature shortfin makos in our data were predominantly female but that Maia et al. (2007) found the majority of specimens taken off the coast of Portugal to be male is consistent with this hypothesis. Incorporating more distribution data from the Northeast Atlantic Ocean is needed to fully understand demographic structure and seasonal movement patterns of shortfin makos in the North Atlantic Ocean.

The identification of pupping and nursery areas for sharks is crucial to protect vulnerable life stages and support conservation goals (Heupel et al., 2007; Kinney and Simpfendorfer, 2009; Heupel et al., 2018). Unless movement following birth is substantial, the distribution of the youngest age classes should delineate potential birthing and nursery areas. Although the distribution data of mature females from this study and others (Branstetter, cited in Depperman, 1953; Branstetter, 1981; Gilmore, 1993; Mollet et al., 2000) indicates that the Gulf of Mexico is a possible 


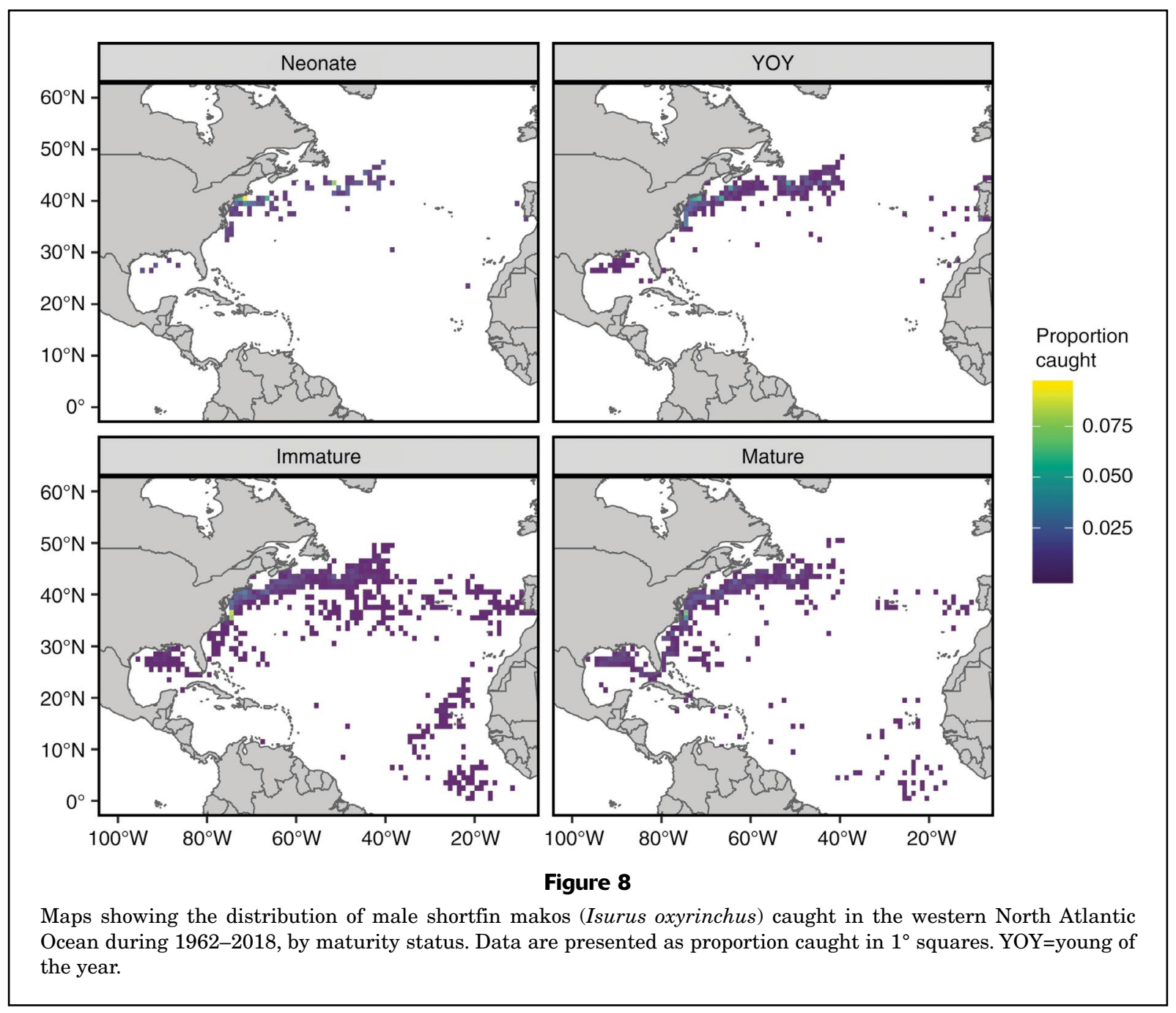

gestation and parturition area from winter to spring, the distribution of neonates is much more widespread along the coast of North America and largely overlaps with the distribution of older immature sharks and adults. Neonate and YOY shortfin makos have also been found off Africa and Portugal (Maia et al., 2007), in waters that may prove to be important birthing or nursery areas with more intensive sampling in the Northeast Atlantic Ocean.

The suggestion of a nursery ground of some degree off Portugal is supported by Maia et al. (2007), who reported captures of birth-size individuals $\left(<70 \mathrm{~cm} \mathrm{FL}_{\mathrm{OTB}}\right)$ in May and July. Maia et al. (2007) question the probability of pups swimming against the current to migrate from a southern pupping ground to Portugal. However, the new evidence of northern pupping on the western side of the Atlantic Ocean indicates that there could also be pupping on the northern area of the eastern Atlantic Ocean or that pups may be using northern surface currents to move from the western to the eastern Atlantic Ocean. Because the coastal areas off Portugal are considered unattractive to sharks (Maia et al., 2007), portions of the western North Atlantic Ocean, which are productive and the location of many shark nursery grounds (Castro, 1993), may be the main parturition and nursery areas for shortfin makos. Data from long-term tracking studies also indicate considerable use of the shelf between South Carolina and Nova Scotia, Canada, by primarily juvenile shortfin makos (Byrne et al., 2017), but additional fishery-independent data are needed to define these boundaries.

The updated reproductive and maturity estimates for both sexes and spatiotemporal patterns in the distribution of life history stages from this study can be used to improve the reliability of science-based advice, as well as to evaluate the likely effect of conservation measures such as size limits. Conservation measures to protect the shortfin mako have been implemented in commercial and recreational fisheries following the ICCAT $^{5}$ recommendations. For example, in an initial effort to limit mortality and reduce overfishing by recreational fishermen, the United States imposed size limits for 2019 of $210 \mathrm{~cm}$ $\mathrm{FL}_{\mathrm{S}}$ and $180 \mathrm{~cm} \mathrm{FL}_{\mathrm{S}}$ for female and male shortfin makos, respectively. The female size limit is below the new $L_{50}$ and the male limit is just below the new $L_{50}$, indicating that these management measures will reduce but not 
remove fishing pressure on mature individuals. Both the United States and Canada have banned the retention of live shortfin makos by commercial fleets, and Canada prohibited all retention of shortfin makos in recreational fisheries (COSEWIC, in press; Federal Register, 2019). Such measures are timely given that updated projections from the North Atlantic Ocean assessment model indicate continued population declines (ICCAT ${ }^{4}$ ). However, there is still a need to better understand the seasonality and segregation of mature females, gestation, and parturition activities in the Gulf of Mexico and along the continental shelf, to develop mitigation options and aid in stock recovery. Ideally, future work on shortfin makos would rely on increased collection of fishery-independent data from sparsely sampled areas.

\section{Acknowledgments}

We thank the officials and participants of the many shark tournaments between southern New Jersey and Nova Scotia as well as commercial fishermen for allowing us to sample their landed shortfin mako. We also thank the NMFS Pelagic Observer Program for their data. Portuguese data were collected by the National Data Collection Program within the scope of the European Union Data Collection Framework and within project MAKO-WIDE funded by the Portuguese Foundation for Science and Technology (Ref: FAPESP/19740/2014). Lastly, we thank all individuals involved in Canada's At-Sea Observer Program.

\section{Literature cited}

Babcock, E. A., and H. Nakano.

2008. Data collection, research, and assessment efforts for pelagic sharks by the International Commission for the Conservation of Atlantic Tunas. In Sharks of the open ocean: biology, fisheries and conservation (M. D. Camhi, E. K. Pikitch, and E. A. Babcock, eds.), p. 472-477. Blackwell Publishing, Oxford, UK.

Barreto, R. R., W. K. T. de Farias, H. Andrade, F. M. Santana, and R. Lessa.

2016. Age, growth and spatial distribution of the life stages of the shortfin mako, Isurus oxyrinchus (Rafinesque, 1810) caught in the western and central Atlantic. PLoS ONE 11(4): $\mathrm{e} 0153062$. Crossref

Bigelow, H. B., and W. C. Schroeder.

1948. Sharks. In Fishes of the western North Atlantic. Part 1: lancelets, cyclostomes, sharks (J. Tee-Van, C. M. Breder, S. F. Hildebrand, A. E. Parr, and W. C. Schroeder, eds.), p. 59-546. Mem. Sears Found. Mar. Res., Yale Univ. Press, New Haven, CT.

Bradley, D., E. Conklin, Y. P. Papastamatiou, D. J. McCauley, K. Pollock, B. E. Kendall, S. D. Gaines, and J. E. Caselle.

2017. Growth and life history variability of the grey reef shark (Carcharhinus amblyrhynchos) across its range. PLoS ONE 12(2):e0172370. Crossref

Branstetter, S.

1981. Biological notes on the sharks of the north central Gulf of Mexico. Contrib. Mar. Sci. 24:13-34.
Byrne, M. E., E. Cortés, J. J. Vaudo, G. C. McN. Harvey, M. Sampson, B. M. Wetherbee, and M. Shivji.

2017. Satellite telemetry reveals higher fishing mortality rates than previously estimated, suggesting overfishing of an apex marine predator. Proc. R. Soc., B 284:20170658. Crossref

Canty, A., and B. Ripley.

2017. boot: bootstrap R (S-Plus) functions. R package, vers. 1.3-20. [Available from website.]

Casey, J. G., and H. W. Pratt Jr.

1985. Distribution of the white shark, Carcharodon carcharias, in the western North Atlantic. Mem. South. Calif. Acad. Sci. 9:2-14.

Casey, J. G., and N. E. Kohler.

1992. Tagging studies on the shortfin mako shark (Isurus oxyrinchus) in the western North Atlantic. Aust. J. Freshw. Res. 43:45-60. Crossref

Castro, J. I.

1993. The shark nursery of Bulls Bay, South Carolina, with a review of shark nurseries of the southeastern coast of the United States. Environ. Biol. Fish. 38:37-48. Crossref

2009. Observations on reproductive cycles of some viviparous North American sharks. Aqua Int. J. Ichthyol. 15: 205-222.

Clark, E., and K. von Schmidt.

1965. Sharks of the central Gulf Coast of Florida. Bull. Mar. Sci. 15:13-83.

Compagno, L. J. V.

2001. Sharks of the world. An annotated and illustrated catalogue of shark species known to date. Vol. 2: bullhead, mackerel, and carpet sharks (Heterodontiformes, Lamniformes and Orectolobiformes). FAO species catalogue for fishery purposes 1, 269 p. FAO, Rome.

Coelho, R., and R. Muñoz-Lechuga.

2019. Hooking mortality of swordfish in pelagic longlines: comments on the efficiency of minimum retention sizes. Rev. Fish Biol. Fish. 29:453-463. Crossref

Coelho, R., J. Mejuto, A. Domingo, K. Yokawa, K.-M. Liu, E. Cortés, E. V. Romanov, C. da Silva, F. Hazin, F. Arocha, et al.

2018. Distribution patterns and population structure of the blue shark (Prionace glauca) in the Atlantic and Indian Oceans. Fish Fish. 19:90-106. Crossref

COSEWIC (Committee on the Status of Endangered Wildlife in Canada).

In press. COSEWIC status report on shortfin mako Isurus oxyrinchus Atlantic population. COSEWIC, Ottawa, Canada.

Cortés, E.

1998. Demographic analysis as an aid in shark stock assessment and management. Fish. Res. 39:199-208. Crossref

2002. Incorporating uncertainty into demographic modeling: application to shark populations and their conservation. Conserv. Biol. 16:1048-1062. Crossref

2004. Life history patterns, demography, and population dynamics. In Biology of sharks and their relatives (J. C. Carrier, J. A. Musick, and M. R. Heithaus, eds.), p. 449-470. CRC Press, Boca Raton, FL.

Cortés, E., F. Arocha, L. Beerkircher, F. Carvalho, A. Domingo, M. Heupel, H. Holtzhausen, M. N. Santos, M. Ribera, and C. Simpfendorfer.

2010. Ecological risk assessment of pelagic sharks caught in Atlantic pelagic longline fisheries. Aquat. Living Resour. 23:25-34. Crossref

Depperman, B.

1953. Maternity model mako. Sports Afield, March.

Dulvy, N. K., J. K. Baum, S. Clarke, L. J. V. Compagno, E. Cortés, A. S. Domingo, S. Fordham, S. Fowler, M. P. Francis, C. Gibson, et al. 
2008. You can swim but you can't hide: the global status and conservation of oceanic pelagic sharks and rays. Aquat. Conserv. 18:459-482. Crossref

Federal Register.

2004. Atlantic highly migratory species (HMS); pelagic longline fishery. Fed. Regist. 69:40734-40758. [Available from website.]

2019. Atlantic highly migratory species; shortfin mako shark management measures; final amendment 11. Fed. Regist. 84:5358-5377. [Available from website].

Francis, M. P.

2006. Morphometric minefields-towards a measurement standard for chondrichthyan fishes. Environ. Biol. Fish. 77:407-421. Crossref

Francis, M. P., and C. Duffy.

2005. Length at maturity in three pelagic sharks (Lamna nasus, Isurus oxyrinchus, and Prionace glauca) from New Zealand. Fish. Bull. 103:489-500.

Francis, M. P., S. E. Campana, and C. M. Jones.

2007. Age under-estimation in New Zealand porbeagle sharks (Lamna nasus): is there an upper limit to ages that can be determined from shark vertebrae? Mar. Freshw. Res. 58:10-23. Crossref

Gilmore, R. G.

1993. Reproductive biology of lamnoid sharks. Environ. Biol. Fish. 38:95-114. Crossref

Haddon, $\mathrm{M}$.

2011. Modelling and quantitative methods in fisheries, 2nd ed., 465 p. CRC Press, Boca Raton, FL.

Hamlett, W. C.

1999. Male reproductive system. In Sharks, skates and, rays: the biology of elasmobranch fishes (W. C. Hamlett, ed.), p. 444-470. Johns Hopkins Univ. Press, Baltimore, MD.

Hamlett, W. C., and T. J. Koob.

1999. Female reproductive system. In Sharks, skates, and rays: the biology of elasmobranch fishes (W. C. Hamlett, ed.), p. 398-443. Johns Hopkins Univ. Press, Baltimore, MD.

Harry, A. V., A. J. Tobin, and C. A. Simpfendorfer.

2013. Age, growth and reproductive biology of the spot-tail shark, Carcharhinus sorrah, and the Australian blacktip shark, C. tilstoni, from the Great Barrier Reef World Heritage Area, north-eastern Australia. Mar. Freshw. Res. 64:277-293. Crossref

Haulsee, D. E., M. W. Breece, L. M. Brown, B. M. Wetherbee, D. A.

Fox, and M. J. Oliver.

2018. Spatial ecology of Carcharias taurus in the northwestern Mid-Atlantic coastal ocean. Mar. Ecol. Prog. Ser. 597:191-206. Crossref

Heupel, M. R., J. K. Carlson, and C. A. Simpfendorfer.

2007. Shark nursery areas: concepts, definition, characterization and assumptions. Mar. Ecol. Prog. Ser. 337: 287-297. Crossref

Heupel, M. R., S. Kanno, A. P. B. Martins, and C. A. Simpfendorfer. 2018. Advances in understanding the roles and benefits of nursery areas for elasmobranch populations. Mar. Freshw. Res. 70:897-907. Crossref

Jensen, C. F., L. J. Natanson, H. L. Pratt Jr., N. E. Kohler, and

S. E. Campana.

2002. The reproductive biology of the porbeagle shark (Lamna nasus) in the western North Atlantic Ocean. Fish. Bull. 100:727-738.

Kinney, M. J., and C. A. Simpfendorfer.

2009. Reassessing the value of nursery areas to shark conservation and management. Conserv. Lett. 2: 53-60. Crossref
Kohler, N. E., and P. A. Turner.

2019. Distribution and movements of Atlantic shark species: a 52-year retrospective atlas of mark and recapture data. Mar. Fish. Rev. 81(2):1-93. Crossref

Kohler, N. E., J. G. Casey, and P. A. Turner.

1995. Length-weight relationships for 13 species of sharks from the western North Atlantic. Fish. Bull. 93:412-418.

Maia, A., N. Queiroz, H. N. Cabral, A. M. Santos, and J. P. Correia. 2007. Reproductive biology and population dynamics of the shortfin mako, Isurus oxyrinchus Rafinesque, 1810, off the southwest Portuguese coast, eastern North Atlantic. J. Appl. Ichthyol. 23:246-251. Crossref

Mollet, H. F., G. Cliff, H. L. Pratt Jr., and J. D. Stevens.

2000. Reproductive biology of the female shortfin mako, Isurus oxyrinchus Rafinesque, 1810, with comments on the embryonic development of lamnoids. Fish. Bull. 98:299-318.

Mucientes, G. R., N. Queiroz, L. L. Sousa, P. Tarroso, and D. W. Sims.

2009. Sexual segregation of pelagic sharks and the potential threat from fisheries. Biol. Lett. 5:156-159. Crossref

Natanson, L. J., and B. J. Gervelis.

2013. The reproductive biology of the common thresher shark in the western North Atlantic Ocean. Trans. Am. Fish. Soc. 142:1546-1562. Crossref

Natanson, L. J., N. E. Kohler, D. Ardizzone, G. M. Cailliet, S. P. Wintner, and H. F. Mollet.

2006. Validated age and growth estimates for the shortfin mako, Isurus oxyrinchus, in the North Atlantic Ocean. Environ. Biol. Fish. 77:367-383. Crossref

Patterson, K., R. Cook, C. Darby, S. Gavaris, L. Kell, P. Lewy,

B. Mesnil, A. Punt, V. Restrepo, D. W. Skagen, et al.

2001. Estimating uncertainty in fish stock assessment and forecasting. Fish Fish. 2:125-157. Crossref

Pratt, H. L., Jr.

1996. Reproduction in the male white shark. In Great white sharks: the biology of Carcharodon carcharias. Proceedings of the symposium on the biology of the white shark; Bodega, CA, 4 March 1993 (A. P. Klimley and D. G. Ainley, eds.), p. 131-138. Acad. Press, San Diego, CA.

Pratt, H. L., Jr., and J. G. Casey.

1983. Age and growth of the shortfin mako, Isurus oxyrinchus, using four methods. Can. J. Fish. Aquat. Sci. 40: 1944-1957. Crossref

Quinn, T. J., II.

2003. Ruminations on the development and future of population dynamics models in fisheries. Nat. Resour. Model. 16:341-392. Crossref

$\mathrm{R}$ Core Team.

2018. R: a language and environment for statistical computing. R Foundation for Statistical Computing, Vienna, Austria. [Available from website.]

Reinhardt, J. F., J. Weaver, P. J. Latham, A. Dell'Apa, J. E. Serafy, J.A. Browder, M. Christman, D. G. Foster, and D. R. Blankinship. 2018. Catch rate and at-vessel mortality of circle hooks versus J-hooks in pelagic longline fisheries: a global metaanalysis. Fish Fish. 19:413-430. Crossref

Rigby, C. L., R. Barreto, J. Carlson, D. Fernando, S. Fordham, M. P. Francis, R. W. Jabado, K. M. Liu, A. Marshall, N. Pacoureau, et al.

2019. Isurus oxyrinchus. The IUCN Red List of Threatened Species 2019: e.T39341A2903170. [Available from website.]

Tanaka, S., G. M. Cailliet, and K. G. Yudin.

1990. Differences in growth of the blue shark, Prionace glauca: technique or population? In Elasmobranchs as living resources: advances in the biology, ecology, systematics, 
and status of the fisheries (H. L. Pratt Jr., S. H. Gruber, and T. Taniuchi, eds.), p. 177-187. NOAA Tech. Rep. NMFS 90. Walker, T. I.

2005. Reproduction in fisheries science. In Reproductive biology and phylogeny of Chondrichthyes: sharks, rays and chimaeras (W. C. Hamlett, ed.), p. 81-127. Science Publishers Inc., Enfield, NH.
Wickham, H.

2017. tidyverse: easily install and load the 'tidyverse'. $R$ package, vers. 1.2.1. [Available from website.]

Zuur, A. F., E. N. Ieno, and C. S. Elphick.

2010. A protocol for data exploration to avoid common statistical problems. Methods Ecol. Evol. 1:3-14. Crossref 